\title{
Karskustöö sünnitab eugeenikaliikumise
}

Ken Kalling

Teesid: 19. sajandil hakkasid loodusteadused, eeskätt evolutsiooniõpetus, avaldama ühiskonnakäsitlustele üha tugevamat mõju. Kujunesid ideoloogiad, mida tuntakse sotsiaaldarvinismi, eugeenika, solidarsimi jne nime all. Ühiskonnakäsitluste n-ö biologiseerumine leidis aset mitmete kanalite kaudu. Üks neist oli karskusidee.

Eesti organiseeritud karskusliikumises valitsesid 19. ja 20. sajandi vahetusel kaks protsessi: süvenev loodusteaduslike ideede mõju (meditsiin ja tervishoid) ning karskusliikumise tsentraliseerimine ja juhtrolli üleminek kohtadelt nn rahvusliku eliidi kätesse, kes nägi karskusliikumises eeskätt rahvusliku liikumise vahendit - karskustöö pidanuks tagama "rahvuskeha" elujõu. Viimasele oli suunatud ka eugeeniline ideoloogia ja seetõttu võib väita, et Eesti eugeenikaliikumine on välja kasvanud karskusliikumisest. Kujunes välja kaks suunda: otsene ja kaudne karskustöö. Eugeenilises liikumises, mis institutsionaliseerus 1924. aastal, olid esindatud karskusliikumise mõlemad suunad, lisaks ka sotsiaaldemokraatlik vool. Iseseisvas Eestis jätkasid karskusorganisatsioonid tööd ja tugevnesid. Pärast 1934. aastal riigis aset leidnud pööret totalitarismi suunas võib täheldada eugeenilise liikumise tugevnemist karskusliikumise arvel.

Märksõnad: eugeenika, karskusliikumine, rahvuslik liikumine, solidarism

Karskuse propageerimine oli oluline ja esmane sisend, mille kaudu (loodus)teaduste pakutavad tõed alates 19. sajandist lihtrahvani jõudsid. Eesti kohta kirjutab karskustegelane Villem Ernits (1891-1982), et karskusseltsid olid esimeseks vabaharidustöö vormiks rahvahulkadele (Ernits 1920: 28). Arst Juhan Luiga (1873-1927) mainib alkoholivastase võitluse positiivse küljena aga seda, et alkoholi kahju tundma õppides õpime ka ennast tundma (Luiga 1995a: 13), pidades sealjuures (kirjutise üldise tonaalsuse põhjal) silmas teadmisi inimkehast, selle funktsioneerimisest ja tervishoiust. J. Luiga seostab karskusteema ka eugeenikaga, ühe olulisimaga neist õpetusist, mis inimühiskonna seletamisel loodusteadustest abi otsisid. 
Eugeenilisele ideoloogiale alusepanija Francis Galton (1822-1911) kirjutas, et tema loodud õpetus on teadus, mis tegeleb kõigi teguritega, mis parandavad rassi kaasasündinud omadusi (Galton 1904). Eugeenika põhines teadmistel darvinismist, pärilikkusest jm loodusteadustest, kaldudes neid ühest küljest nii üksikindiviidi kui ka populatsiooni (ühiskonna) arengus ületähtsustama, teisalt avaldades muret selle üle, et loodusliku valiku printsiibid inimliigi puhul ei toimi - moraal, religioon jms toetavad pigem olukorda, mis soodustab alaväärsete ellujäämist. Eugeenikud eeldasid, et sekkumine inimliigi arengusse on vajalik, soodustamaks bioloogiliselt väärtuslikumate inimindiviidide sigimist, seega tulevaste põlvkondade tervist ja tugevust. Teaduse kujunemist ideoloogiaks soodustas ajastule omane ühiskonnakäsitluste üldine biologiseeritus (medikaliseeritus). Lihtsustatult - Jaan Tõnissoni (1868-1941?) poolt öelduna on eugeenika (ka: rassihügieen, tõutervishoid) inimese zootehniline tõuaretus:

Peame, kuigi see zyniliselt kõlab - oma "tõuuraamatut" tegema, nagu neid karjakasvatajad oma puhastverd loomade jaoks peavad, sest neil on kulturaloos suur väärtus [---] Suur vale on, et inimene neid tõdesid oma kohta maksma ei pane, mis ta loomade juures tarvitab (Tõnisson 1912: 17).

Eeldused eugeenilise ideoloogia introdutseerimiseks eesti ühiskonda olid olemas - juba enne iseseisvumist räägiti eestlaste tõu kehvast kvaliteedist ja muretseti kvantiteedi pärast. Eugeenikaselts loodi Eestis pärast iseseisvuse saavutamist - 1924. aastal. Seltsi eesmärgiks oli viia ellu iibepoliitikat, tõhustada rahvatervishoiu meetmeid jne (Kalling 1998). Seltsi töö oli ühiskonnas kuuldav, nt ületasid uudisekünnise 1927. ja 1935. aasta rahvusliku kasvatuse kongressid. Konstantin Pätsi (1874-1956) režiimi (nn vaikiva ajastu) aastatel võeti Eestis vastu eugeenilise sisuga seadusandlikke akte (steriliseerimisseadus 1936. aastal; samal aastal algas rahvatervise kuusaastak jne).

Kuigi vaikival ajastul liberaliseeris riik alkoholipoliitika (Ant 1989: 4446), eemaldudes sellega karskusliikumise ideaalidest, tasub meeles pidada, et paradoksaalselt soodustas karskusliikumine solidaristlik-korporatiivse ühiskonnakorralduse väljakujunemist (tunnusteks rahvusterviklikkuse kontseptsioon, eugeenilise liikumise esiletõus, naiste suunamine soospetsiifiliste funktsioonide juurde jms), mis andis näo sõjaeelse Eesti riigi lõpuaastatele.

Ajaloole tagasi vaadates võib öelda, et kuigi vanem kui eugeeniline ideoloogia, taandus karskusliikumine oma teatavas faasis vaid üheks osaks 20 . sajandi esimesel poolel domineerima pääsenud eugeenilis-tõutervishoidlikust 
maailmapildist. Käesolev artikkel vaatlebki eeskätt perioodi, mil karskustöös valitsesid arstiteaduslikud ja bioloogilised õpetused, ning jälgib, kuidas karskusliikumise raames tekkis Eesti eugeenikaliikumine. Lisaks kohalike karskus- ja eugeenilise liikumise ajalugude ühe etapi tutvustamisele osundab uurimus ka teadusideede retseptsiooni viisidele ühiskonnas, näidates, milline areng võib iseloomustada ühte eliidiprojekti, milleks osa karskusliikumisest ajaloo teatavas faasis saab. Artikkel aitab ehk süvendada arusaamist olulistest paralleelidest, mis esinevad Eesti poliitilise mõtte ja karskusideoloogia vahel ning seega ka karskusliikumise kaudsetest mõjudest rahvusriigi tekkeprotsessidele.

\section{Karskusliikumise ajaloost Eestis}

Kodumaise karskusliikumise ajaloo kohta on olemas mõned käsitlused, ka käesoleva töö autor on andnud oma panuse (Kalling 2002). Olemasolevad kirjutised on siiski pigem institutsiooni ajalugu vaatlevad (Karu 1989; Ant 1989; Vahtre 1997). Eranditeks võib ehk pidada Lembit Raidi kirjutist bolševike vaadetest karskusele (Raid 1989) ning eriti Otu Ibiuse (1904-1975) 1939. aastal valminud, paraku käsikirja jäänud viievihikulist ülevaatlikku uurimust kodumaisest karskusliikumisest (Ibius 1939). Karskusliikumisest on säilinud arvukalt nii trükitud allikaid kui ka arhiivimaterjale. Teema on oluline ka tänapäeval, leides loodetavasti edaspidigi uurimist.

Karskusideed tungisid Eestisse koos vennastekogudustega 18. sajandil (Põldmäe 1938). Esimene faas haaras kaasa ka kohalikke meedikuid nagu Peter Ernst Wilde (1732-1785), Johann Wilhelm Ludwig von Luce (1750-1842) ja Friedrich Reinhold Kreutzwald (1803-1882), kes tuginesid oma aja tervishoiu autoriteetidele (Christoph Wilhelm Hufeland (1762-1836)) ja oli pigem klerikaalne. See etapp kestis 19. sajandi lõpuveerandini. Tekkisid rahvaliikumise alged, nt 1830.-1840. aastail Eestisse levinud karskusvannete andmise komme (Ibius 1939, 1: 120-123, 131-135).

Uus periood Eesti karskusliikumises kujunes 1880. aastail, mil Soome eeskujul hakati asutama karskusseltse (esimene oli Täht Toris 1889. aastal). See oli seltside asutamise kõrgaeg karskusliikumises - kuni 1903. aastani loodi neid Eestis 61 (siis hakkas arv kahanema) (Karu 1989: 9). Samal ajal hakati moodustama karskusseltside üleriiklikke ja ülerahvuslikke keskorganisatsioone - Eestis loodi säärane 1907 (Karu 1989: 12). Sellised katusorganisatsioonid aga võisid teinekord olla ka liikumise sees tekkiva võõrandumise allikaks, millest edaspidi ka näiteid. 
19. ja 20. sajandi vahetus oli uus ajastu karskusliikumises ka sellepoolest, et kui seni oli liikumise eesmärk olnud eeskätt paternalistlik (liht)inimeste vara ja hinge päästmine, siis arengu uues etapis hakkas domineerima altpoolt lähtuv initsiatiiv, mis nägi eesmärgina laiemat ühiskondlikku emantsipatsiooni. Lisaks hakkasid karskusliikumises olulist rolli mängima loodus- ja arstiteadustest pärit teooriad.

Viimane käib ka rahvusliku liikumise kohta, nt Juhan Luiga arvates pidanuks rahvaste elusündmuste hindamist praeguselt harilikult traditsiooniliselt, ajalooliselt seisukohalt loodusteaduslikule alusele viima (Luiga 1995b: 221). Hans Kruus märgib, et eesti rahvuslus, olles saksa vastava ideoloogia mõju all, sattus koos sellega 19. sajandi teisel poolel loodusteaduslike tõuteooriate mõju alla ning hakkas samuti põhinema tõutervendamise õpetusel (ning siit lähtus H. Kruusi arvates ka J. Tõnissoni huvi karskusliikumise vastu) (Kruus 1921: 89-90). Samalaadse tähelepaneku rahvuskäsitluse biologiseerumisest (vihjates eugeenikale) teeb Eduard Laamann:

Enne 1905. a. tembeldas rahvusline vool marxismi tema aadete lameduse pärast "kõhuorjuseks". Pärast 1905., kui rahvuslus ise oma ideoloogiat hakkas selgitama, tuli ilmsiks, mis tema enda "kõrge pilvedetagune aade” oli. See oli - karjakasvatus (Laamann 1915: 41).

Karskusteema medikaliseerumine ja rahvuskäsitluse biologiseerumine leidsid aset osaliselt sõltumatult, samas ka vastastikku teineteist võimendades. Neile tendentsidele, sh ka eugeenika arengut hoogustanud lähenemistele, lisandus karskusliikumise muutmine eesti rahvusliku liikumise vahendiks, st süvenes elitaristlik aspekt - altpoolt tuleva initsiatiivi järkjärguline allasurumine ja eliidi domineerimine.

\section{Eesti karskustegelaste loodusteaduste retseptsioon}

Karskusidee lähenemist loodusteaduslikele ja meditsiinilistele doktriinidele toetasid arvukad teadusteooriad, mis käsitlesid alkoholi kahjulikkust järeltulevale soole (Üprus 1931). Eesti eugeenilise mõtte juured saavad alguse eeskätt nn degeneratsiooniteooriast.

Degeneratsiooni mõiste võttis 1850. aastatel kasutusele prantsuse psühhiaater Benedict Augustine Morel (1809-1873), kes seletas selle kaudu arsti- ja loodusteadlaste seas üles kerkinud küsimusi (vaimu)haiguste (jm regressiilmingute) tekkest ja levikust. B. A. Morel leidis, et vaimuhaigused on sageli vanematelt lastele edasi antavad ja järglaspõlvkondades kuhjuvad: esimene degenereeruv põlvkond kujutab endast lihtsamate närviviga- 
de all kannatajaid, eluoluga kohanematuid jm, järgmises põlvkonnas annavad tooni neuroosid, alkoholism ja nt langetõvehood, kolmas põlv on juba tõsiselt vaimuhaige ning neljandas domineerivad väärarendid, nõdramõistuslikkus ja steriilsus (kui vahepeal ei lisandu tervendavat värsket verd) (Mattila 1999: 27-28).

Selle teooria valguses on degeneratsioon suunatud protsess (erinevalt pärilikkusest, mis kujundlikult on pigem staatiline olek, potentsiaal). Kuigi varasematesse degeneratsioonistaadiumidesse kuulunud põlvkondi iseloomustas B. A. Moreli jt arvates pigem keskmisest kõrgem sigivus, mis kinnitas eugeenikute hirmu alaväärsete osa suurenemise ees populatsioonis, järgneb sellele degenereeruva suguvõsa või rahva järkjärguline allakäik, viies lõppkokkuvõttes väljasuremiseni. Hirm füüsilise väljasuremise ees on väikerahvalikust enesetunnetusest kantud eesti rahvuslikule mõttele olnud omane juba üle sajandi (Karjahärm \& Sirk 2001: 259-265).

Kuivõrd degeneratsiooni mõiste kujunes olukorras, kus pärilike ja kaasasündinud defektide olemusel ei pruugitud veel vahet teha, oli degeneratsiooni oletatavate põhjustajate skaala lai: mürgitumine (alkohol, muud mõnuained, aga ka tee ja kohv, riknenud toit), ebatervislik kliima, puudulik hügieen, epideemiad ja haigused (nt süüfilis, tuberkuloos ja leepra), tehiskeskkond (tööstus, korteriolud, linnastumine, nn lõbukultuur), vaimuhaigused ja haiglaslikud iseloomujooned (epilepsia, hüsteeria jms), moraaliga seotud haiguslikud nähud (kuritegelikkus), kaasasündinud haigused ja traumad (sünnitraumad, pimedus, kurttummus, ajukahjustused) ning ka pärilikkus selle tänapäevases mõistes. Samuti hakati anti- või asotsiaalsust (isegi klassikuuluvust) seostama degeneratsiooniga. Asotsiaalsuse kriteeriumide alla mahtus omakorda nt ka vallalisus, naistel lastetus jms.

Alkoholi sidus degeneratsioonitemaatikaga juba B. A. Morel. Samasugust käsitamist tunti ka Eestis (nt J. Tõnisson jt). 1922. aastal kirjutas Peeter Põld (1878-1930):

Vanemate isegi mõõdukas alkoholi tarvitamine rohkendab laste seas - see on teadusliselt vastuvaidlemata kindlaks tehtud - haiglust, andevaesust, totrust ja mitmesuguseid kadumisele ning kidunemisele viivaid närvihaigusi. Veelgi enam [nüüd opereerib P. Põld juba ka ajastu pärilikkusõpetusest lähtuvate ideedega - autor]: vanemate alkoholism nõrgestab kui protoplasma kihvt ihusugu juba tema saamise momendil. Meie järeltulev sugu muutub seega, kui alkoholi valitsusele lõppu ei tehta, tulevikus järjest nõrgemaks, meie arv aga mitte suuremaks (Põld 1922: 9). 
Sarnasest arusaamisest lähtuvalt introdutseeris dr Juhan Luiga, karskustööd tegev psühhiaater, eestikeelsesse diskussiooni ka eugeenika algtõed, tehes seda 1900. aastal avaldatud kirjutises, mis käsitleb alkoholi mõju vaimuhaigustesse. Selles on lause, mis juhib meid degenereerumise juurde:

Vägev on vaimuhaigete mõju selle läbi, et ta pärandusena ühe inimese päält tema lastele edasi jääb. Selle läbi saab vaimuhaigus seltskonna, rahva haiguseks ja võib ajaga terve rahvasoo ära õonestada (Luiga 1995a: 18).

J. Luiga jätkab sotsiaaldarvinistlike teemaarendustega:

${ }^{3}{ }_{4}$ vaimuhaigetest on oma koorma vanemate pärandusena kaasa saanud. Looduse pü̈̈d, sund on niisuguseid nõrku, kahjulikke isikuid kahjutuks teha, ilmast hoopis ära kaotada, et rahvast puhastada (Luiga 1995a: 18).

Ta leiab, et nagu meri, nii puhastab ka ühiskond end ise looduslike vahenditega. J. Luiga tsiteerib B. A. Morelit ja teatab, et selline puhastamine võtab inimliigi juures aega vähemalt neli inimpõlve. Halb olevatki nimelt see, et protsess nii kaua kestab - seni jõuab halb sugu veel palju tõugu rikkuda, sest: Pärandatud haigus võib ennast iga põlve juures isesuguseks muuta, aga kaduma ta ei lähe (Luiga 1995a: 18-19).

Siin näeme teatavat näidismõtteviisi, mis pani eugeenikuid tegutsema inimühiskonnas puuduv looduslik valik nõudnuks tuleviku põlvkondade heaolu nimel suunatud valiku läbiviimist.

\section{Jaan Tõnissoni ja Villem Reimani vaated alkoholile}

Degeneratsiooniteooria hiilgeaeg jäi 19. sajandisse. 20. sajandi algul hakkas vanale teooriale konkurentsi pakkuma uus teadusharu - geneetika -, mis tundis juba huvi pärilikkuse rakuliste mehhanismide vastu. Jaan Tõnisson refereeris 1907. aastal August Forelit (1848-1931), kellega ta oli isiklikult kohtunud 1901. aastal Viini karskuskongressil:

Kui need [seemnerakud - K.K.] on alkoholi läbi rikki läinud, kihvtitatud, kui sünnib nii nimetatud "blastoftooria" (seemneidu ja munarakukese kihvtituse läbi tekkiv järeltulijate kidurus [vt ka: Üprus 1931: 121 - K.K.]), siis on lastel nii kehalised kui vaimlised puudused (Tõnisson 1921: 2). 
Formuleerub J. Tõnissoni seisukoht karskustöö alal: karskusliikumine tähendab võitlust uue ilmavaate pärast (Tõnisson 1907: 9). Uus ilmavaade omab Eesti oludes - lisaks rahva kvaliteedile tähelepanu pööramisele - ka tugevat kvantiteeti tähtsustavat aspekti:

Hü̈̈d: “Kas olemine või mitte-olemine?” - see on lõpuarveks võitluses alkoholi vastu (Tõnisson 1907: 8).

1907. aastaks oli J. Tõnisson jõudnud oma karskusmõtte pinnal tõuküsimuse (Rassenhygiene) ehk eugeenika juurde: Isegi need, kes rahvuse mõtet eitavad, peavad tõuaate sunnil karskuse poole lööma (Tõnisson 1907: 8). Rahvust mõistetakse siin n-ö kultuurrahvusena (Karjahärm \& Sirk 1997: 212-214), vastandades seda bioloogilisele rahvuse käsitlusele (mis eksisteeris tõu kontseptsiooni kujul). Viimane oli paljudele toonastele mõtlejatele oluline meetod eestluse defineerimisel - lisaks juba tsiteerimist leidnud J. Luigale mainitagu ka nt Ado Grenzsteini (1865-1916) ja Villem Grünthal Ridalat (1885-1942) (Karjahärm 1993).

J. Tõnisson väitis Ameerika indiaanlaste näitel, et alkoholi mõjul võivad rahvad, kui nende elujõud alkoholi läbi rikutud [ning] siginemisjõud kahaneb, koguni välja surra (Tõnisson 1907: 5). (Nõrgestatud bioloogilist elutungi peab eesti rahva väikese iibe põhjustajaks nt ka Peeter Põld (Põld 1922: 9).)

J. Tõnissoni vaated olid paraku üsna segased, olles (paljudele toonastele eesti mõtlejaile tüüpiliselt) eklektiline kompilatsioon toona maailmas levinud ideedest (vt nt Jans 1940: 154-155). Kui Villem Ernits võrdleb 1921. aastal J. Tõnissoni karskustegevust Villem Reimani omaga, leiab ta, et J. Tõnisson oligi pigem aatemees, V. Reiman aga olevat rajanud oma tegevuse alkoholivastases võitluses teaduslikule alusele, mh tõuteooriale (Ernits 1921: 29).

Villem Reimani tegevus karskusaate propageerimisel algas juba 1890. aastatel (ka Charles Darwini nimi leiab äramärkimist seoses alkoholi kahjuliku toimega pärilikkusse (Reiman 1924: 30)), kuid saab tõelise hoo sisse 20. sajandi alguses, olles selleks ajaks ka juba tõuteooriast, s.o tervishoiutemaatikast, mõjustatud (Palm 1937: 150-152). 1912. aastal pidas V. Reiman Narvas Eesti Kirjanduse Seltsi koosolekul avamiskõne "Kuidas rahvad surevad". Ta rääkis karskusaatest, tehes seda aga vägagi biologiseeritud kõnepruugis ja väitis, et rahvad surevad siis, kui neis haiguse-idud nähtavale tulevad. Kaovad need rahvad, kes loodusseaduste vastu elavad - nt nii toitumist kui ka sugutungi lõbu maitsmise nimel kasutavad. Sellistel puhkudel algab degeneratsioon, sest loodusseadused, mis ühtlasi kõlbtuse- ja õiguseseadused, on rikutud ja nõuavad armuta tasumist (Reiman 1913: 26). 
V. Reiman märkis ka, et ainestatud ilmavaade [mõeldud on siinkohal vulgaarset evolutsiooniõpetuse käsitlust, nn sotsiaaldarvinismi - K.K.] ei hooli kõlblusest, õigustades suhtumist, et suurem võib väiksema ära sü̈̈a. See aga polevat õige, sest pigem paistab loodusest, et üks olevus teist aitab (Reiman 1913: 26). Viimane märkus võib olla üks põhjusi, miks V. Reiman vasakpoolsete vaadetega Villem Ernitsale sümpatiseerib - on ju antud argumendi näol tegemist suhteliselt tüüpilise vasakpoolse, kui mitte isegi anarhistliku (altruismiteooria tegi tuntuks vürst Pjotr Kropotkin) darvinismitõlgendusega.

\section{Karskusliikumine muutub eliidiprojektiks}

Kuni 1905. aasta revolutsioonile järgnevate aastateni oli eesti karskusliikumises palju soomepärast, nt tugev religiooni mõju (Ibius 1939, 1: 181). Karskusliikumine oli suunatud üksikisikutele, nende moraalsele või materiaalsele heaolule. Kuigi juba 19. sajandil oli Eestis käsitlemist leidnud alkoholi n-ö tõutervisesse puutuv mõju, pääses karskusliikumises laiemalt ühiskonnale suunatud tegevus domineerima alles 1905. aasta revolutsioonile järgnenud rahvusliku idee otsimise käigus (Ibius 1939, 2: 142).

Tekkis olukord, kus eugeenika tähendus muutus üha aktuaalsemaks. Nimelt ilmnes sellises, ühiskonnale laiemas perspektiivis lähenemises eugeenilise ideoloogia oluline kvaliteetne erinevus karskusliikumisest. Eugeenika, toetudes sisuliselt populatsioonibioloogiale, keskendas tähelepanu (ühelt) indiviidilt suuremale rühmale. Eugeenika toetus ka enam meditsiini ja loodusteaduste saavutustele: karskuse-seltside pea-ülesanne on karskusmõtte teadusline propaganda (Tõnisson 1909: 23). Teadusest lähtuvate sihtide seadmine, pidades silmas laiemaid eesmärke, pidanuks aga olema eliidi töö.

Juhtivate rahvusliku liikumise tegelaste jaoks kujunes karskusliikumine aga mitte enam niivõrd eesmärgiks, vaid pigem vahendiks: Karskus on abinõu, mitte siht (Vilms 1923: 41). Teerajaja vastava suhtumise kujunemisel oli olnud Ado Grenzstein, kes märkis, et küll tehakse kära inimeste saksastumise puhul, kuid rahvuskaaslaste põhjajoomist - mis ju veelgi olulisem, sest sisaldab ka bioloogilist komponenti, kaotust rahvuskehale - ei märgata. A. Grenzstein kutsub juba 1885. aastal üles rajama õnnetult lõpetanud Aleksandrikooli komiteede asemel karskuskomiteesid, leides, et joomine ei ole ainult isiklik, vaid (ka) ühiskondlik pahe (Grenzstein 1885). Esimese eestimaise karskusseltsi asutaja Jüri Tilk (1865-1929) vaatles 1896. aastal karskusliikumist samuti poliitiliselt, rõhutades liikumise olulisust just väikerahvale (Tilk 1896: 73). 
Kõrgemale ja kaugemale - n-ö paleuste valda - seatud sihid leidsid paraku massides vähest mõistmist. J. Tõnissoni süüdistatakse, et ta liig teaduslikult, nagu pilvede pealt kõnelenud, asja lihtmehe arusaamisest eemale viinud, neid nagu töö juurest ära tõrjunud (Kuues Eesti karskusseltside kongress 1907: 13). Kohtadel oodati pigem käegakatsutavat paikkondlikku karskustööd (Ibius 1939, 3: 152). Juba 19. sajandi lõpul küsiti Eestis, miks kipub haritlaskond karskusliikumisele võõraks jääma. J. Tõnissoni kommentaarist selgub, et üritus tundub paljudele impordituna (sh ka karskuspropaganda, mis pahatihti näib võõrkeelest tõlgitud kombeõpetuse, mitte praktilise sisuga seisukohavõttudena). Ta leiab, et karskusseltsidel enestelgi puudub veel arusaam oma eesmärkidest (Tõnisson 1898). Teisal kirjutab J. Tõnisson: Meie rahva tuleviku kultuurpaleus ei ole kõigile selge, ei soojenda tarvilikul määral südant ega juhi tegevust (Ibius 1939, 3: 152).

Rahvusliku haritlaskonna rolli karskusliikumise loomisel ja juhtimisel on korduvalt esile toodud (Karu 1989: 12; Vahtre 1997: 967-968). Selles ei pruugi kahelda, sest vastastikune mittemõistmine eliidi ja lihtrahva vahel ei tekkinud mitte klassierinevuste pinnal, vaid ideede tasemel. Küsimus, kuidas karskustööd läbi viia, sisaldas nimelt mitmeid vastuolulisi lahendusi (vt joonis 1). Enne iseseisvumist räägiti palju täiskarskusest ja sellega liikumise sees konkureerivast parajusest. Pärast iseseisvumist said märksõnadeks otsene ja kaudne karskustöö. Otsene karskustöö, mis jätkas varasemat täiskarskuse rõhutamist, nägi alkoholismivastase võitluse peamise meetodina selgitustööd ja isiklikku eeskuju ning rõhutas isiku vaba tahte tähtsust (elu)tee valikul. Kaudne karskustöö oleks keskendunud inimeste vaba aja sisustamisele, nn lõbukultuuri arendamisele.

Karskustöö metoodikas kajastusid ka maailmavaatelised erinevused sotsiaaldemokraadid püüdsid kujundada uusi olusid (kus alkoholil poleks kohta), leides, et alkoholism on ühiskondlik pahe; rahvuslased nägid vaeva uue isiku kasvatamisega, kuivõrd karskusaade pidi põhinema teadlikkusel. Eugeenikute eesmärgiks oli aga uue inimese aretamine.

Tüli konkretiseerus 1923. aasta karskuskongressil, juhatades kätte konkreetse niidiotsa karskusliikumise eugeeniliseks liikumiseks ülemineku protsessis. Mainitud kongressi peetakse esimeseks strateegilisi sihte seadvaks karskusfoorumiks Eesti karskusliikumise ajaloos (Vilms 1923: 35). Kongressil üritati ühendada kahte karskustöös domineerinud suunda, kuid kaudse ja otsese karskustöö pooldajate vahel leidis pigem aset totaalne vastandumine.

Eesti oludes, kus valdavale osale maailmas selles vallas levinud teooriatest sai osaks üsna diletantlik ja eklektiline retseptsioon, leidus eugeenikute 


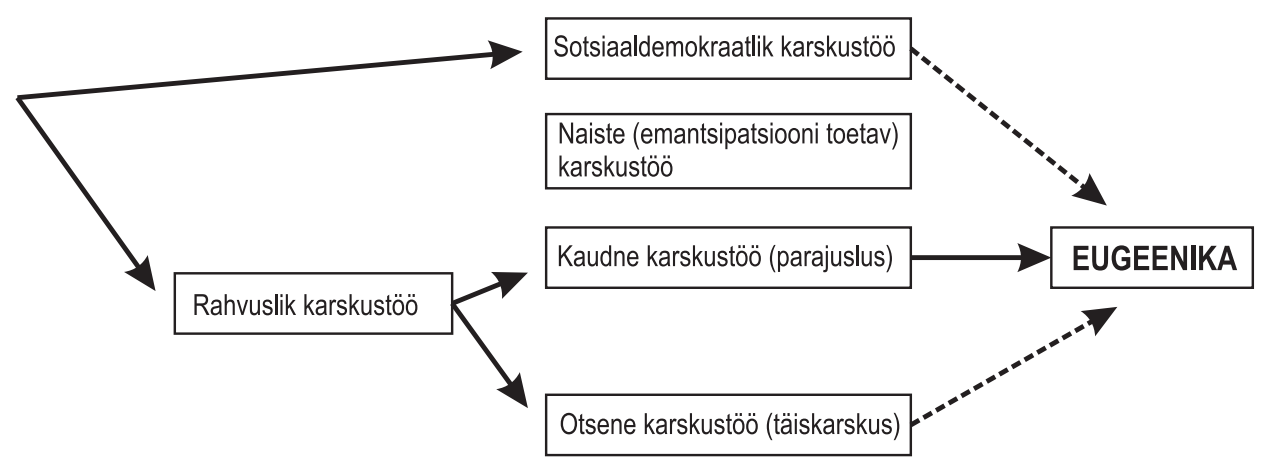

Joonis 1. Karskustöö meetodite pinnal toimunud põhimõtete lahknemine.

seas nii rahvusliku liikumise tegelasi kui sotsialiste. Naiste karskusliikumine, mida käesolevas artiklis ei käsitleta, oli omaette elujõuline fenomen, mis andis välja ajakirja Eesti Naine ning korraldas üleriiklikke emadepäevi. Naiste karskusliikumises oli nii solidaristlikke aspekte (naine = ema) kui emantsipatsiooni ja võrdõiguslikkust jutlustavaid külgi, mis lähendasid seda sotsiaaldemokraatlikele suundumustele.

Kaudse karskustöö toetajate seas domineeris hilisem juhtiv eugeenilise (aga ka korporatiivse) ideoloogia levitaja Juhan Vilms (1893-1952). Tema argumendid kaudse karskustöö kasuks selguvad kriitikast, mida ta tegi otsese karskustöö vastu. Viimane olevat rakendatav vaid arusaajate ja kohusetruude inimeste mõjutamiseks, laiem rahvahulk aga pole mitte mõistusega arusaamise, vaid tundmuste ning lõbu varal ja egoistlikel motiivel elav organism (Vilms 1923: 37). Otsese karskustöö, s.o kihutustöö nõrku külgi näitavat seegi, et senised tulemused on kehvad ja lisaks on kihutustööl eitavad (negatiivset reaktsiooni esile kutsuvad) tagajärjed. Suur ja oluline puudus olevat aga see, et otsese karskustöö pooldajad ei taha rääkida alkoholi levimise põhjustest (Vilms 1923: 38-39). J. Vilms leiab, et vaimustuse asemel peaks karskusküsimus olema kaine arvestuse valdkond, organiseerida on vaja masside vaba aega, lõbukultuuri. Alustada tuleks lihtsast, pidades silmas suuri eesmärke:

Rahva hä̈̈ käekäigu, tervishoiu, tõuparanduse ja ka kõlbluse pärast on tarvis alkoholismi vastu võidelda! Nende sihtide seast kõlbluse siht [kõlblus oli otsese karskustöö tegijate peamine märksõna - K.K.] on võrdlemisi väikene, võrreldes tervishoidliste ja majanduslike alkoholismi pahedega (Vilms 1923: 41). 
Vastasrinna - otsese karskustöö - poolt (lisaks J. Tõnissonile) kõnesoleval kongressil sõna võtnud Peeter Põld süüdistab J. Vilmsi selles, et too, lähtudes monistlikust maailmavaatest (teie, kaudsed, tahate luua kultuuri monistlikku, jättes inimese oma tungide kätte), vaatleb inimesi kui enda tahet mitte kontrollida suutvat inimmassi, kellega karskustegelased manipuleerima peaksid (soovitate inimesega ümber käia kui lojusega: panna ta miljöösse, tuppa, kus ta midagi paha teha ei saa). P. Põld leiab, et kaudse karskustöö propageerijad on suured pessimistid, soovides jätta kõik bioloogilisanimaalsele seisukorrale. P. Põld teeb vihje ka eugeenilisele maailmapildile aluseks saanud paternalistlik-elitaarsele lähenemisele (Platonit, muide, peetakse üheks eugeenilise mõtte loojaks (vt nt Lüüs 1934)):

Meie ei saa Platoga nõus olla, et on inimesi, kes ainult seks elavad, et teiste, filosoofide, toitmise eest hoolt kanda, kes valitsevad (Põld 1923: $62)$.

Seega vastandus prof. P. Põllu seisukoht toonases teaduses valitsevale monistlikule käsitlusele, mis nägi materialistliku ja arvatava idealistliku (vitalistliku) alge esinemist ühes tervikus. P. Põllu arvates oli inimene dualistlik olend (s.o koosnes materiaalsest kehast ja vaimust ehk hingest, kusjuures viimane teeb inimesest inimese):

Teil on kultuur ainult väliste mõnususte kokkuvõte, meil on kultuur kõik see, mis viib looduslisest seisukorrast üle (Põld 1923: 62).

\section{Solidarismi ideede levik Eestis}

Solidarismi puhul on tegemist ühiskondliku solidaarsuse vormiga, mis erineb sotsiaaldemokraatiast - tuntuimast ühiskonnas solidaarsust rõhutavast liikumisest - selle poolest, et eitab klassivõitlust (s.o majanduspoliitilisi vahendeid võrdsete võimaluste loomiseks), üritades selle asemel tekitada ühiskonnaüleseid, rahvakihte ühteliitvaid, klassi- jm vastuolusid eitavaid paleusi (tuntud on selles kontekstis fašistide ja natsionaalsotsialistide pseudomütoloogiad, Eestis oli oluline rahvusterviklikkuse mõiste). Solidarismist reaalpoliitika kontekstis rääkides kasutatakse tavaliselt terminit korporatiivne ühiskond.

Solidaristlik hoiak lähtus ajastule omastest mõttevooludest, mis olid alguse saanud Saksamaal reaktsioonina darvinismile, täpsemalt selle ja sotsiaaldemokraatia koostoimel tekkida ähvardava vasakpoolsuse tugevnemisele. Alternatiivse, solidaarsust käsitleva maailmapildi aluseks olid RudolfVircho- 
wi (1821-1902) rakuteooria (rakupatoloogia), goethelik morfoloogia, haeckellik evolutsiooniõpetuse tõlgendus ja monistik filosoofia (Weindling 1989: 4048). Selles valguses vaadeldi ka inimpopulatsioone (nt konkreetset rahvast) kui elusorganisme, milles inimesed, elukutsed, sotsiaalsed kihid ja rühmad jne oleksid käsitletavad rakkude, kudede, organitena jne ning ka kultuur jms oleks biologiseeritud. Siit lähtuvalt oleks igal indiviidil ühiskonnas oma kindel positsioon, kohustused suure organismi ees jms. Tekkinud oli olukord, kus bioloogia sai - vastandina toona darvinismi levitatavale liberaalsele suunale - traditsiooni ja stratifikatsiooni jutlustavaks jõuks.

Solidarism võib panustada riigile või rahvuslikele aadetele, kusjuures üksikisik peaks olema allutatud riigi (st üldise) huvidele. Solidarism - seda näitas ajalugu - võis saada aluseks totalitaarsete ühiskondade poliitilistele süsteemidele. Seda seetõttu, et solidarism eeldab sageli nn eliiti (juhti), lisaks kodanlikku demokraatiat välistavat korporatiivset süsteemi (elukutsed kui spetsialiseerunud koed ja organid), sageli ka soospetsiifilist, naisemantsipatsiooni eitavat tööjaotust (naised kui ühiskondliku organismi reproduktiivne pool). Nähtust saab iseloomustada selle kriitiku, liberaalse poliitiku J. Tõnissoni sule läbi:

[---] isikul ei ole iseenesest mingit väärtust, vaid et see on ainult üks väikene asjakene, mis ei saa mitte "rahvakeha" arengut takistada [---] (Kruus 1938: 578).

Ka eugeenikat, dominantset ja subdominantset poolust eristavat meditsiinilis-paternalistlikku lähenemist võib käsitleda solidaristliku fenomenina.

Solidaristliku maailmavaate esiletõus Eestis on seostatav eeskätt nn radikaalsete haritlaste - kelleks eeskätt alates 1907. aastast end Endiste Eesti Ülioopilaste Seltsiks Ühendus kutsuv liikumine, kuid ka Noor-Eesti - tegevusega. Seltsil nimega Ühendus olid varakult kontaktid ka karskusliikumisega ja teatud üksmeel sotsiaaldemokraatidega (Jans 1931: 28-35). Ühenduse mõned liikmed tegelesid darvinismi propageerimisega, kuid tuleb siiski tunnistada, et selline varajane vasakpoolne tegevus jäi peaasjalikult loodusteadusliku materialismi tasemele (Raid 1978: 39).

Pärast 1905. aasta revolutsiooni sai ka Eesti Üliõpilaste Seltsist (EÜS), kes seni oli sageli materialismi eitanud, loodusteadusi oma ideoloogilises arsenalis kasutav liikumine, seda teataval määral isegi sotsiaaldemokraatlikke paleusi silmas pidades - nt rõhutatakse eriliselt arenguideed (Koppel 1910: 3). Selts Ühendus kaldus samal ajal aga loodusteaduste retseptsiooni kontekstis solidarismi, nt üllitas Ernst Haeckeli kogutud teosed (Haeckel 1914) (EÜS avaldab aga Ch. Darwinile pühendatud kogumiku). Kuigi nõu- 
kogude ajalookirjutus käsitles Ühendust ja selle mõningaid liikmeid kui näidet kohaliku eliidi kaldumisest vene progressiivse mõtte suunas (Raid 1978: 37-41), ollakse hilisemates seltsi liikmete tagasivaadetes seisukohal, et oldi pigem saksa teaduse lainel, sest vene oma teadus oli liiga idealistlik (Jans 1931: 28).

Ühendus tunnistas eesti rahvusliku mõtte kujundamisel liidrina NoorEesti liikumist, mis samuti kaldus solidarismi (Ruubel 1918: 54). Põhjendatakse seda 1905. aasta sündmustega:

1905. a. liikumise kandja oli altruistlik utilitarism, kui see kõikuma lõi, tekkis "naiivile silmavaatele" vastuolu - isiku ja olude, isiku ja ilmavaate vahel (Laamann 1918: 43).

Vastuolu püüti ületada mitmel moel. Noor-Eesti pööras pilgud oludelt inimesele (Laamann 1918: 42). Isegi sotsialismi katsuti mugandada. Hans Kruus nt üritas ühendada individualismi sotsiaalsega, väites, et sotsialismi aluseks olevat väga sügav ja omapärane individualism: sotsialism on sotsiaalpoliitiline vorm, individualism selle eetiline sisu. H. Kruus leidis, et tema ja ta mõttekaaslaste ideoloogiaks sai sotsialistlik individualism (Kruus 1918: 37-38).

Seltsiga Ühendus seotud tegelastest said hiljem tuntud eugeenikud (Hans Madissoon, Juhan Vilms, Karl Toomingas) või vastava liikumise toetajad. Ühenduse ridadest võrsusid ka peamised korporatiivse ideoloogia - kutsekodade süsteemi - ideoloogid ja teostajad, eeskätt jällegi Juhan Vilms, aga ka Konstantin Päts. J. Vilmsis olid ühendatud nii eugeenik, karskustegelane kui ka aktiivne poliitik, korporatiivse ühiskonnakorralduse propageerija (viimast 1930. aastail). Eelmises peatükis kirjeldasime teda kui sisult eugeenilise, kaudse karskustöö propageerijat.

Eesti avaliku elu politiseerumisest sai aga karskusliikumise üks lõhestajaid. Näeme rahvuslaste võõristust sotsiaaldemokraatia vastu. Juba enne iseseisvumist, eriti aga selle esimestel aastail, hakati karskusliikumist käsitama kui vasakpoolsusega (mida paljud vaatlesid stigmatiseerituna) seostatavat fenomeni. Põhjust selleks oli - meenutagem kas või Hans Pöögelmanni (1875-1938) osalemist karskustöös (Vahtre 1997: 970) või V. Ernitsat sotsiaaldemokraatide ridades Riigikogus. 1927. aastal, arutades riigipoolset toetust karskusliikumisele, peeti Riigikogus vihane arutelu selle üle, kas karskustegevus on sotsialism või rahvuslus. Isegi J. Tõnisson pidi ümber lükkama tema kohta lendu lastud väite, nagu esindaks ta sotsiaaldemokraatia huvisid (III Riigikogu protokollid: vrg 1238). 
Aga ka rahvuslus ei vastanud radikaalide soovidele, sest kippus oma paleuste pinnal reaalsusest võõrduma. Seega olid loodud tingimused, et kahe suuna - sotsiaaldemokraatia ja liberaalse rahvusluse - vahele sai tekkida solidaristlik suund, milles iseseisvuse eel nähti väljapääsu ühelt poolt rahvuslasi iseloomustanud alalhoidlikkusest, teiselt poolt sotsiaaldemokraatiast.

Iseseisva Eesti poliitilisel maastikul oli solidaristlik suund põhjustatud demokraatia kriisist, olles kompromiss parteide lehmakauplemise ja vaikiva oleku ehk ajastu vahel. Karskusliikumises oli solidaristlik-monistlik suund samuti kompromissiks, mis, erinevalt rahvuslasist pidas vajalikuks vaadelda ka alkoholismi põhjusi, jättes samas otseselt sotsialistide kombel ründamata ühiskonna alused ja kujundades rahvusterviklikkuse ideest lähtudes vastuvõetavamat keskkonda, milles rahvatervist, s.o riiklust arendada. Selleks keskkonnaks oli eugeenika.

\section{Karskusliikumisest sünnib eugeenika}

Eugeenilised noodid siginesid Eestis karskustemaatikasse juba enne 19. ja 20. sajandi vahetust (Ibius 1939: 4: 115). Arstiteaduslik kuukiri Tervis andis alkoholiküsimuse käsitlusele nii mõnegi rea (Koppel 1907), ilmus ka vastavasisulist tõlkekirjandust (Bunge 1904).

Alkoholi tarbimise käsitlemise patologiseerimine oli karskusliikumise eugeenika suuna väljaarenemise oluline eeltingimus - oli ju eugeenikute eesmärgiks peamiselt inimtõu tervendamine. Protsessi võimendas arstide osavõtt karskustööst ja karskusliikumise üha laiahaardelisem tegevus, sh tervishoiu vallas. Siinkohal väärib meenutamist, et arstikutset üldiselt iseloomustas toona tendents, mis viis kutse esindajad haiguste ravijaist (tagajärgedega tegelejaist) üha enam ennetajate suunas (ka see toetas eugeenilist ideoloogiat ühiskonnas).

Iseseisvas Eestis esines Arstide Liidu juhatus korduvalt initsiatiiviga mõõduka keeluseaduse toetamiseks, alkoholimüügi kitsendusteks jne. Initsiaatoriks selles vallas oli sageli arstikutseta isik - nt filoloog Villem Ernits, toonane Eesti Karskusliidu esimees. V. Ernitsa idee luua arstide karskusselts leidis pooldamist, kuid teoks ei saanud see kunagi (Kolmas Eesti Arstide päev 1925: 29).

Iseseisvuse algusaastateks organisatsiooniliselt tõeliselt mastaapseks muutunud Karskusliit plaanis 1923. aasta sügisel korraldada tervishoidlise lennu, mille esialgu kavandatud kolmele teemale (üldine tervishoid, külgehakkavad haigused, 3 tähtsamat sotsiaalset haigust - tuberkuloos, suguhaigused ja alkohol) lisandus veel üks: rahvaarvu juurdekasv (EAA 2389-2- 
185: 7 ja 19). Lendu tutvustavates lendlehtedes on retoorika üsna eugeenikamaiguline: Asutatakse pulliseltse, aga inimese tervisele ei mõelda! (EAA 2389-2-185: 88). Ähvardati toonastele kodumaistele eugeenikutele omaselt ka demograafilise kriisiga. Üritus leidis aset, kuid aasta pärast, septembris 1924 tegi Karskusliit ettepaneku jätkata vastavat traditsiooni juba vastloodud Eesti Eugeenika Seltsi Tõutervis ettevõtmisena (EAA 2389-2-185: 305). (Meenutagem, et 1923. aastal oli esile kerkinud teatav eugeenika suunas viiv lõhenemine karskusliikumise sees, st vastuolu otsese ja kaudse karskustöö pooldajate vahel.)

Karskusliikumise ajaloo kirjutanud Otu Ibius mainib, et eugeenika seltsi kutsusid ellu karskusliikumisele lähedased ringkonnad (Ibius 1939, 4: 115). Professor Aadu Lüüs meenutab:

Sajandi algusest peale on Gobineau [ilmselt on nn eugeenika isa Francis Galton (1822-1911) segi aetud Gobineau'ga, n-ö rassismi isaga autor] mõju Eestis tunda, nii arsti- kui loodusteaduses. Nende uurimuste pioneeriks oli dr. J. Luiga, siis tuli pastor Willem Reiman, alkoholismi vaenlane. Jaan Tõnisson, lugupeetud riigimees, moodustab mainitutega kolmiku, kes propageeris geneetika printsiipe (Gobineau ja Tartu 1934: 236).

II rahvusliku kasvatuse kongressil mainis A. Lüüs kodumaise eugeenikaseltsi asutajatena väikest gruppi haritlasi, peamiselt arste, loodusteadlasi ja advokaate (Madissoon 1935: 7).

Eugeenikute ja karskustegelaste töö oli samasuunaline: Nii üks kui teine sihib kehaliselt ja vaimliselt terve ja elujõulise seltskonna ja rahva saavutamise poole. Ka töömeetodid - kasvatustöö (rahvale parema elusisu andmine [---] sügavam elukäsitus, kõlblisem ja soliidsem alus peab olema meie isiklisel ja seltskondlisel elul) - olevat samad. Seega leidus palju ühist liikumiste põhjustes, sihtides ja abinõudes (Tõutervise ja karskusliikumise vahekorrast 1925: 1-2). Eesti Vabariigis leidsid endale koha nii karskustegelased kui eugeenikud, tehes ka koostööd.

\section{Kokkuvõtteks}

Jääb mulje, et iseseisvuse edenedes karskustöö tähtsus eesti ühiskonnas vähenes, samal ajal kui eugeenikute positsioon kindlustus. Pätsi ajastu alkoholipoliitika tagurlikkusele siin kirjutises juba vihjati. Viinamüügi liberaliseerimine oli siiski ilmselt pigem majanduspoliitiline samm, astutud riigikassa täitmiseks. Ideoloogiliselt aga - ja vaikival ajastul, seega ka riiklikust 
vaatevinklist - sobis eugeenikute poolt esiletõstetav iibehüsteeria masside liigutamiseks paremini kui vasakpoolsuse (või naisliikumisena) ühiskonna alustalasid õonestada püüdev karskusliikumine.

Ometi olid eugeenika, nagu ka vaikiva ajastu korporatiivne ühiskonnakorraldus oma juurtega karskustöös. Karskusliikumine oli Eesti riigi tekkimisele seega oluline mitte vaid institutsionaalsest aspektist, vaid suur oli karsklaste panus ka rahvusliku ideoloogia kujunemisse.

\section{Arhiiviallikad}

EAA 2389-2-185. Eesti Ajalooarhiiv. Eesti Karskusliit. Tervishoidlik lend 1923-1925. Ibius, Otu 1939. Eesti karskusliikumise ajalugu. I-V vihik. Käsikiri Tartu Ülikooli Raamatukogu käsikirjade ja haruldaste raamatute osakonnas (KHO 127-105, 106, 107, 108, 109).

\section{Kirjandus}

III Riigikogu: III istungjärk: [18. jaan. - 20. mai 1927]: Protokollid nr 35-90. Tallinn 1927.

Ant, Jüri 1989. Alkoholipoliitikast ja karskusliikumisest Eestis 1920-1940. Silvet, Erki (koost). 100 aastat karskusliikumist Eestis 1889-1989. Tallinn: Eesti Raamat, lk 3860 .

Bunge, Gustav von 1904. Mikspärast ei suuda palju emasid oma lapsi ise imetada ja mikspärast on niisuguste emade arv järjest kasvamas? Tervis 5: 65-75.

Madissoon, Hans (peatoim) 1935. Eesti rahva tulevik: II rahvusliku kasvatuse kongressi kõned ja läbirääkimised. Eesti Eugeenika ja Genealoogia Seltsi toimetused. Tartu: Tulevik.

Ernits, Villem 1920. Karskusliikumine ja haridustöö Eestis: Kiri Eesti haridusseltsidele. Karskus ja haridus. Eesti Karskusseltside Kesktoimekonna toimetused 67. Tartu: Eesti Karskusseltside Kesktoimkond, lk 27-31.

Ernits, Villem 1921. Villem Reiman karskustegelasena. Tulev Eesti: Jõulualbum. Karskusseltside Kesktoimkonna kirjastus 81. Tartu: Eesti Karskusseltside Kesktoimkond, lk 27-30.

Galton, Francis 1904. Eugenics: Its Definition, Scope, and Aims. Read before the Sociological Society at a Meeting in the School of Economies (London University), on May 16, 1904. The American Journal of Sociology X: 1 (July) (http://galton.org/essays/19001911/galton-1904-am-journ-soc-eugenics-scope-aims.htm - 5. juuni 2006).

Gobineau ja Tartu 1934. Looming 2, lk 235-236. 
Grenzstein, Ado 1885. Joomise vastu. Olevik 21-23.

Haeckel, Ernst 1914. Loodus ja inimene: Viis päätükki. Eesti üliõpilaste seltsi "Ühenduse" toimetus. Tartu: Noor-Eesti.

Jans, Johan 1931. 25 aastat. Eesti Üliõpilaste Selts "Ühendus": 1906-1931. Tartu: Ühendus, lk 20-38.

Jans, Johan 1940. Mälestusi ja vaatlusi I. Tartu: Noor-Eesti.

Kalling, Ken 1998. Tõutervishoiust ja sundsteriliseerimisest Eestis. Kleio 2, lk 27-31.

Kalling, Ken 2002. Jaan Tõnisson Eesti karskusliikumise ideoloogina. Viru, Atko-Meeme \& Volver, Anne (toim). Teadusvaade alkoholile. Tartu: Eesti Karskusliidu Karskusühendus AVE, lk 146-157.

Karjahärm, Toomas 1993. Tõuküsimus Eestis iseseisvuse eel: Historiograafiline referaat. Akadeemia 7, lk 1347-1364.

Karjahärm, Toomas \& Sirk, Väino 1997. Eesti haritlaskonna kujunemine ja ideed 18501917. Tallinn: Eesti Entsüklopeediakirjastus.

Karjahärm, Toomas \& Sirk, Väino 2001. Vaim ja võim: Eesti haritlaskond 1917-1940. Tallinn: Argo.

Karu, Ellen 1989. Pilk Eesti karskusseltside algusaastaisse. Silvet, Erki (koost). 100 aastat karskusliikumist Eestis 1889-1989. Tallinn: Eesti Raamat, lk 8-29.

Kolmas Eesti arstidepäev. 1925. Eesti Arst, lisa, lk 28-30.

Koppel, Hendrik 1907. Alkohol, arstiteadus ja arstid: XI üleilmlisel karskuse kongressil Stockholmis 1907. Tervis, 5. ak, lk 49-62.

Koppel, Hendrik 1910. Eessõna. Eesti Üliõpilaste Seltsi Album 8: Looduseteaduse osakonna väljaanne. Tartu: Eesti Üliõpilaste Selts, lk 1-4.

Kruus, Hans 1918. *** (Olime rühm kooliõpilasi, pärastisi rahvakooliõpetajaid Tartu “pädagoogide kloostris”...) Kümme aastat: Noor-Eesti 1905-1915. Tartu: Noor-Eesti, lk 34-40.

Kruus, Hans 1921. Jaan Tõnisson Eesti kodanluse juhina. Tartu: Odamees.

Kruus, Hans 1938. J. Tõnisson kaugvaates. Kruus, Hans et al. (toim). Jaan Tõnisson töös ja võitluses: Koguteos tema seitsmekümnenda sünnipäeva puhul. Tartu: Koguteose “Jaan Tõnisson" komitee, lk 573-589.

Eesti karskusseltside kongress 6, Tartus, Eesti Üliõpilaste Seltsi ruumides, 4.ja 5. augustil 1907. 1907. Eesti Karskusseltside Kesktoimkonna kirjastus 5. Tartu: Eesti Karskusseltside Kesktoimkond.

Laamann, Eduard 1915. Tõutervendus Eestis. Vaba Sõna 2, lk 40-46.

Laamann, Eduard 1918. *** (Minu esimesed kindlamad mälestused Noor-Eestist on...). Kümme aastat: Noor-Eesti 1905-1915. Tartu: Noor-Eesti, lk 41-43.

Luiga, Juhan 1995a. Alkohol - vaimuhaiguste sünnitaja. Luiga, Juhan. Mäss ja meelehaigus. Tartu: Ilmamaa, lk 13-22. 
Luiga, Juhan 1995b. Rahvaste tõus ja langemine. Luiga, Juhan. Mäss ja meelehaigus. Tartu: Ilmamaa, lk 210-227.

Lüüs, Aadu 1934. Plato eugeenika õpetajana. Eesti Arst 8, lk 589-590.

Mattila, Markku 1999. Kansamme parhaaksi: Rotuhygienia Suomessa vuoden 1935 sterilisointilakin asti. Bibliotheca historica 44. Helsinki: Suomen historiallinen seura.

Palm, August 1937. Villem Reiman: Saavutusrohke rahvuslik võitleja. Suurmeeste elulood 40. Tartu: Eesti Kirjanduse Selts.

Põld, Peeter 1922. Eesti riigi tulevik ja karskus. Eesti Karskusseltside Kesktoimkonna väljaanne 95. Tartu: Eesti Karskusseltside Kesktoimkond.

Põld, Peeter 1923. Sõnavõtt. Johanson (= Elango), Julius (toim). Eesti Karskusliidu asemikkudekogu koosolek nime all Eesti XIII karskuskongress: Tartus 24. ja 25. veebruaril 1923. a.: Protokoll. Eesti Karskusliidu väljaanne 114. Tartu: Eesti Karskusliit, lk 58-63.

Põldmäe, Rudolf 1938. Eesti vennastekoguduste võitlus rahva joomapahega. Eesti Kirjandus 6, lk 281-293.

Raid, Lembit 1978. Vabamõtlejate ringidest massilise ateismini: Marksistlik ateism Eestis aastail 1900-1965. Tallinn: Eesti Raamat.

Raid, Lembit 1989. Karskusküsimus ja Eesti bolševikud. Silvet, Erki (koost). 100 aastat karskusliikumist Eestis 1889-1989. Tallinn: Eesti Raamat, lk 30-37.

Reiman, Villem 1913. Kuidas rahvad surevad? Sõnavõtt. Eesti Kirjanduse Seltsi aastaraamat V (1912). Eesti Kirjanduse Seltsi Toimetused 12. Tartu: Eesti Kirjanduse Selts, lk 25-27.

Reiman Villem 1924. Kas elutilk või surnumeri. Villem Reiman’i mälestuseks. Tartu: s.n., lk 28-31.

Ruubel, Peeter 1918. Noor-Eesti ja poliitika. Kümme aastat: Noor-Eesti 1905-1915. Tartu: Noor-Eesti, lk 48-61.

Tilk, Jüri 1896. Karskuse küsimus - suur rahvuslik küsimus. Tilk, Jüri (toim). Eesti Karskuse Seltside Kalender 1896. Tartu, lk 72-73.

Tõnisson, Jaan 1898. Kolmas üleüldine Eesti karskuskoosolek. Postimees 3.

Tõnisson, Jaan 1907. Sõnavõtt. Kuues Eesti karskusseltside kongress. Eesti Karskusseltside Kesktoimkonna kirjastus 5. Tartu: Eesti Karskusseltside Kesktoimkond, lk 7-9.

Tõnisson, Jaan 1909. Sõnavõtt. Kaheksas Eesti karskuseseltside kongress. Eesti Karskuseseltside Kesktoimkonna Kirjastus 21. Tartu: Eesti Karskusseltside Kesktoimkond, lk 22-23.

Tõnisson, Jaan 1912. Sõnavõtt. Eesti Kirjanduse Seltsi aastaraamat IV (1911). Eesti Kirjanduse Seltsi Toimetused 11. Tartu: Eesti Kirjanduse Selts, lk 16-19.

Tõnisson, Jaan 1921. Alkoholivabast kultuurist: Jaan Tõnissoni kõne Karskus-kõnekoosolekul Ülikooli aulas 13. nov. 1921. Karskusseltside Kesktoimkonna kirjastus 82. Tartu: Karskusseltside Kesktoimkond. 
Tõutervise ja karskusliikumise vahekorrast. 1925. Tulev Eesti 1, lk 1-2.

Vahtre, Lauri 1997. Karskusseltsid Eesti riikluse sünnis. Akadeemia 5, lk 957-971.

Vilms, Juhan 1923. Sõnavõtt. Johanson (= Elango), Julius (toim). Eesti Karskusliidu asemikkudekogu koosolek nime all Eesti XIII karskuskongress: Tartus 24. ja 25. veebruaril 1923. a.: Protokoll. Eesti Karskusliidu väljaanne 114. Tartu: Eesti Karskusliit, lk 35-45.

Üprus, Voldemar 1931. Kaalutlusi vanemate alkoholismi sugujärglasi kahjustava toime piiritlemiseks. Eesti Arst 2, lk 117-123.

Weindling, Paul 1989. Health Race and German Politics between National Unification and Nazism, 1870-1945. Cambridge Studies in the History of Medicine. Cambridge: Cambridge University Press.

\section{Summary}

\section{Estonian abstinence work constructing the eugenics movement}

\section{Ken Kalling}

Key words: the temperance movement, eugenics, solidarism, national movement

Estonia between the two world wars was among the few societies in Europe to have a strong eugenics movement (eugenics society was established in 1924) and to accept eugenic legislation (Sterilisation Law from the year 1936). The roots of the eugenics ideology reach into the pre-independence era, when, in the end of the 19th and the beginning of the 20th century the Estonian national discourse was notoriously biologized owing to the so-called small nation's self perception, highlighting, and both the quality and quantity issues of the "national body".

The birth of the eugenics ideology in Estonia can be linked to the developments in the local abstinence movement. The latter, which emerged in the $1880 \mathrm{~s}$, became by the early 20 th century medically oriented and dominated by the leaders of the national movement who tried to use the initiative for political goals. The latter aspect gave the movement a paternalist accent, alienating the national elites from the masses involved in the movement.

There was also a gap within the ideological framework of the movement itself, taking place between the proponents of the so-called direct and indirect anti-alcohol work. The first, representing mainly the modest and liberal section of the national elites, stressed the people's free will and personal choice. The second wing, deriving from radical intellectuals, many of which later turned to solidarism, favoured the imposing of limitations and regulations by the society to keep people away from alcohol. This approach was criticized by the liberals for the paternalist approach it was containing, rendering human beings to plainly biological entities. This also played an 
important role in the increasing significance of the anti-alcohol movement in supporting the emergence of a eugenic society.

The Estonian eugenics movement and the ideology it was carrying reached its peak in 1934 when the state followed an autocratic/totalitarian path of development. The concept supporting antidemocratic developments was "national entirety", the latter containing a notorious degree of solidarist (biologized) approach. It was the era when the parallel histories of eugenics and the temperance movement started to move apart - the eugenics ideology being preferred by the state as it placed its own interests, rather than the interests of individual citizens, to the fore. 